\section{Shade Affects Yield and Stem Length of Field-grown Cut-flower Species}

\author{
A.M. Armitage \\ Department of Horticulture, University of Georgia, Athens, GA 30602
}

Additional index words. Centaurea americana, basket flower, Eryngium planum, sea holly, Echinops ritro, globe thistle, Anemone coronaria, poppy anemone, Zantedeschia, calla lily, irradiance, harvest duration

\begin{abstract}
Various field-grown specialty cut-flower species were subjected to full sun or $55 \%$ or $67 \%$ shade treatments for 2 to 3 years. Plants grown in shade had longer flower stems than those grown in ambient irradiance; however, yield (flower stems per plant) was species-dependent. Yield of Centaurea americana Nutt. 'Jolly Joker', an annual speices, and Eryngium planum L., a perennial, declined linearly with each reduction in irradiance. However, yield of Echinops ritro L. 'Taplow Blue', a perennial species, was higher in 55\% shade than in ambient irradiance. Yield of transplants and tubers of Anemone coronaria L. 'De Caen' were not affected by planting material (transplants or tubers). Plants grown under $67 \%$ shade had the longest stems starting 3 weeks after the beginning of harvest and the difference persisted for an additional 4 weeks regardless of planting material. A quadratic decline in yield in three of four cultivars of Zantedeschia Spreng. occurred as shade increased, but yield was similar for ambient and 55\% shade. Scape length and spathe width increased as shade increased, although some cultivars were more responsive than others.
\end{abstract}

Numerous ornamental plant species are grown in the field for cut-flower production in the United States. Crops other than carnations, roses, and chrysanthemums are loosely defined as "specialty cut flowers" (Armitage, 1990) and many are produced in the field (Klusmeyer and Martens, 1990). Actual economic value of specialty cut flowers in the United States is unknown, but their importance has risen significantly in the last 5 years. While wholesale volume of carnations, chrysanthemums, and roses remained level or declined between 1987 and 1990, the value of "other cut flowers" rose $56 \%$ in that period (U.S. Dept. of Agriculture, 1989, 1991). A conservative wholesale value of specialty cut flowers in 1990 was about $\$ 173$ million, greater than a combined total of standard and miniature carnations, standard and pompon chrysanthemums, and sweetheart roses (\$125 million) (U.S. Dept. of Agriculture, 1989, 1991). Although most specialty cut crops are produced in the field or under minimum protection, some crops, such as Gypsophila paniculata L., Limonium latifolium (Sm). 0 Kuntze, Lilium spp. L., and Salvia leucantha Cav., are forced in greenhouses during peak demand times. California, Hawaii, and Florida are the leading producers of specialty cut flowers, but a growing number of producers are found in many other states.

Received for publication 18 Sept. 1990. I thank Judy Laushman for her assistance; Yoder Bros, Alva, Fla., for financial support of this work; and Ball Seed Co.. West Chicago. Ill.. and Barrie MacKenzie, B.L. MacKenzie Horticulture, New Zealand, for supplying the anemones and calla lilies, respectively. The cost of publishing this paper was defrayed in part by the payment of page charges. Under postal regulations, this paper therefore must be hereby marked advertisement solely to indicate this fact.
High irradiance is associated with inductive plants (Halevy, 1984). Flowering in roses (Post and Howland, 1946; Zeislen and
Halevy, 1975), geranium (Armitage and Wetzstein, 1984; Craig and Walker, 1963), and carnations (Bunt, 1973; Holley, 1959) is reduced or delayed as irradiance is reduced. Providing shade is an effective means of reducing irradiance, but low irradiance has also been shown to increase internode elongation (Armitage et al., 1990).

The objective of this research was to determine the effects of shade on yield (flowers per plant) and stem length of annual (Centaurea), perennial (Echinops, Eryngium), and bulbous (Anemone, Zantedeschia) species grown in climatic zone $7 b$ (U.S. Dept. of Agriculture, 1990). The influence of shade on spathe width of Zantedeschia flowers was also determined.

Raised beds, $\approx 2 \mathrm{~m}$ wide and $15 \mathrm{~m}$ long, were constructed in 1985 near Athens, Ga., climatic zone $7 \mathrm{~b}$. Composted equine manure was incorporated into the natural Cecil clay loam soils and the beds were filled 0.6 to $0.8 \mathrm{~m}$ deep with the compost-clay mixture. The beds were exposed to full sun and irrigated overhead when necessary. Shade beds were constructed by stretching one or two pieces of neutral blackcloth (Chicopee Manufacturing, Atlanta) $\approx 1.5 \mathrm{~m}$ above the medium. The cloth was extended to encompass the sides and ends of the shade treatment area. Irradiance was measured for each treatment area with a LI-COR 6000 light meter
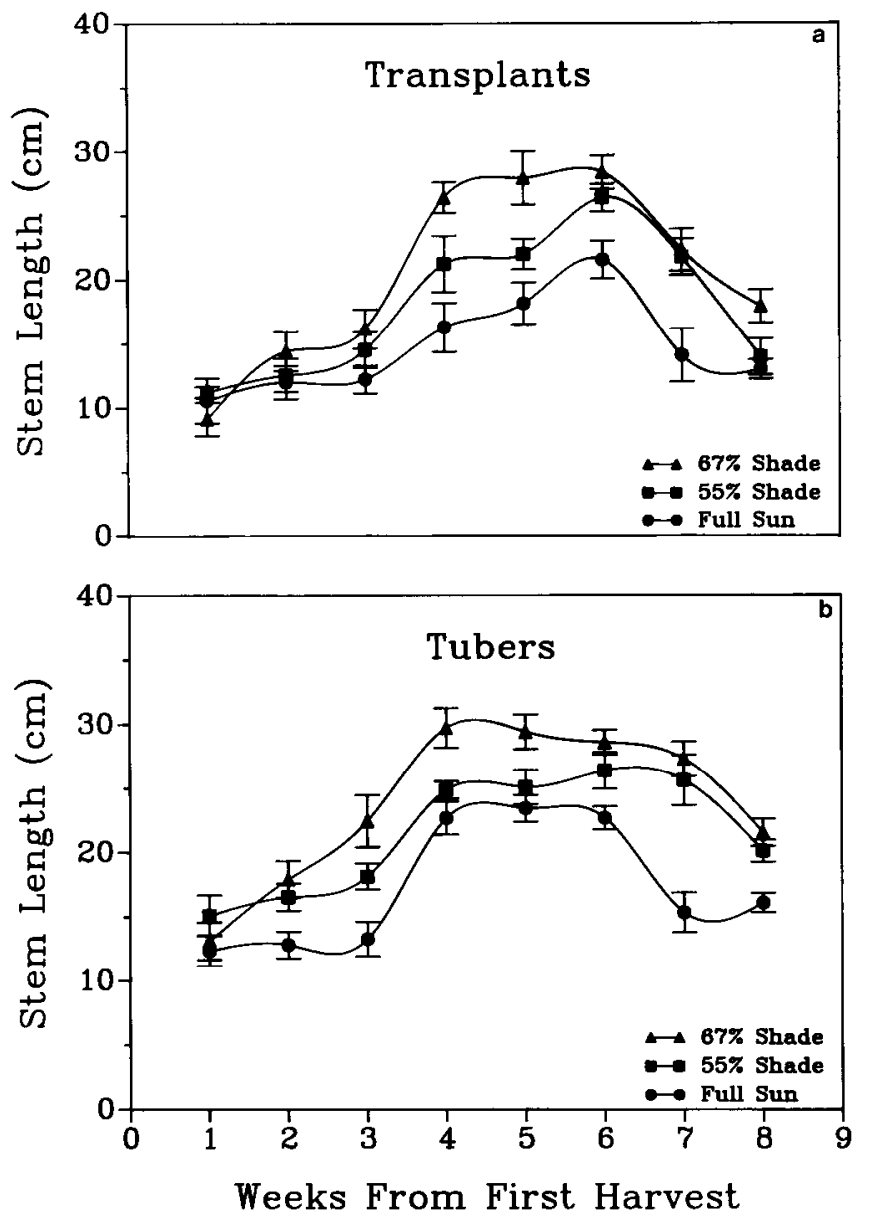

Fig. 1. The influence of shade and harvest date on stem length of Anemone coronaria 'De Caen' grown from (a) transplants or (b) tubers. Vertical lines represent 1 SE. 
Table 1. The effect of shade on field-grown cutflower species.

\begin{tabular}{lcc}
\hline \hline $\begin{array}{c}\text { Shade level } \\
(\%)\end{array}$ & $\begin{array}{c}\text { Yield } \\
\text { (stems/plant) }\end{array}$ & $\begin{array}{c}\text { Stem length } \\
\text { (cm) }\end{array}$ \\
\hline \multicolumn{3}{c}{ Centaurea americana Jolly Joker } \\
0 & 13.1 & 38.3 \\
55 & 7.3 & 54.0 \\
67 & 3.0 & 47.1 \\
Linear & $*$ & $*$ \\
Quadratic & NS & $*$ \\
& Echinops ritro Taplow Blue \\
0 & 4.7 & 82.4 \\
55 & 6.8 & 107.5 \\
67 & 5.8 & 100.1 \\
Linear & $*$ & $*$ \\
Quadratic & $*$ & $*$ \\
\multicolumn{4}{c}{} \\
0 & Eryngium planum & \\
55 & 7.0 & 92.4 \\
67 & 5.2 & 88.6 \\
Linear & 1.1 & 100.3 \\
Quadratic & $*$ & $*$ \\
NS, Nonsignificant or significant at $P=0.05$.
\end{tabular}

Table 2. The influence of shade on four cultivars of Zantedeschia.

\begin{tabular}{|c|c|c|c|}
\hline $\begin{array}{c}\text { Shade level } \\
(\%)\end{array}$ & $\begin{array}{c}\text { Yield } \\
\text { (stems/plant) }\end{array}$ & $\begin{array}{c}\text { Scape } \\
\text { length } \\
(\mathrm{cm})\end{array}$ & $\begin{array}{l}\text { Spathe } \\
\text { width } \\
\text { (cm) }\end{array}$ \\
\hline \multicolumn{4}{|c|}{ Majestic Pink } \\
\hline 0 & 9.0 & 37.0 & 5.0 \\
\hline 55 & 7.3 & 60.0 & 5.4 \\
\hline 67 & 1.7 & 64.1 & 5.2 \\
\hline Linear & $*$ & $*$ & ns \\
\hline Quadratic & $*$ & NS & NS \\
\hline \multicolumn{4}{|c|}{ Pink Perfection } \\
\hline 0 & 9.0 & 38.0 & 4.6 \\
\hline 55 & 8.3 & 56.2 & 7.1 \\
\hline 67 & 2.7 & 59.5 & 7.0 \\
\hline Linear & $*$ & $*$ & $*$ \\
\hline Quadratic & * & $*$ & $*$ \\
\hline \multicolumn{4}{|c|}{ Pacific Pink } \\
\hline 0 & 7.0 & 37.0 & 4.8 \\
\hline 55 & 6.8 & 52.3 & 6.6 \\
\hline 67 & 1.3 & 51.6 & 6.7 \\
\hline Linear & * & * & * \\
\hline Quadratic & * & * & $*$ \\
\hline \multicolumn{4}{|c|}{ Black Magic } \\
\hline 0 & 11.2 & 46.0 & 6.1 \\
\hline 55 & 8.3 & 58.3 & 6.4 \\
\hline 67 & 3.0 & 68.2 & 6.6 \\
\hline Linear & * & $*$ & $*$ \\
\hline Ouadratic & NS & NS & NS \\
\hline
\end{tabular}

(LI-COR, Lincoln, Neb.) on a sunny and a cloudy day. Areas covered with one piece of cloth were $\approx 55 \%$ shaded and those with two received $\approx 67 \%$ shade. These treatments were selected after preliminary data from 1984 and 1985 indicated that $55 \%$ shade was necessary for significant results in some field-grown species. Temperature for each treatment was measured with copper-constantan thermocouples on sunny and cloudy days. In general, the temperature under $67 \%$ shade was 2 to $3 \mathrm{C}$ lower than full sun and 1 to $2 \mathrm{C}$ lower than $55 \%$ shade on a bright day. No differences in temperature were detected during cloudy periods.

One-hundred-eight tubers and 108 transplants (three replications of 12 tubers or transplants per treatment) of Anemone coronaria 'De Caen Mix' were planted 2.5 to $3 \mathrm{~cm}$ apart on 15 Oct. 1987 in a factorial design (planting material $\times$ shade). Fiftyfour plants of Echinops ritro and Eryngium planum were planted in Oct. 1985 and three replications of six plants each were used for each shade treatment. Plants were grown 45 $\mathrm{cm}$ apart and were in their 2nd year of production when the data were obtained (1987). Transplants (180) of Centaurea americana 'Jolly Joker', three replications of 20 plants in each treatment, were planted $30 \mathrm{~cm}$ apart on 2 May 1987. Fifty-four 4-cm-wide rhizomes (three replications of six plants per treatment) of Zantedeschia hybrids were planted $45 \mathrm{~cm}$ apart on 13 Oct. 1985. Yield, scape length, and spathe width were recorded when spathes were completely unfolded. The number of flowering stems per plant and the stem length were determined in 1987 for all species except Anemone (1988). Data were tested by analysis of variance using a completely randomized design, except for Anemone (factorial design), and the treatment means were subjected to trend analysis.

\section{Anemone}

Significant differences in survivability occurred between tubers and transplants. Only $62 \%$ of the tubers emerged and flowered, while $95 \%$ of the transplants produced flowers. The reasons for the poor emergence are unknown. Yield (four to six flowers per flowering plant) was similar, regardless of planting materials or irradiance treatment (data not shown). Shade treatments affected stem lengths of flowers produced from corms and transplants similarly. Both produced the longest stems under the least amount of light (Fig. 1). Flower stems were shortest in the early stages of harvest but increased in length as the season progressed (Fig. $1 \mathrm{a}$ and b). This pattern is similar to that reported by Klusmeyer and Martens (1990) in which the longest stems also occurred in early harvest periods in the greenhouse. For transplants, significant differences in stem length due to shading occurred after the 3rd week of harvest and continued until the 5th week (Fig. la). Stems in full sun were shorter than those in $67 \%$ shade after the first week of harvest. Similar patterns of stem growth occurred with tubers (Fig. lb), although stems of plants in full sun never attained the length of those grown in 55\% shade. Significant differences in stem length between shade treatments occurred by week 3 and were maintained until week 6 . No other differences between planting materials were observed. The data with Anemone suggest that heavy shade can be recommended to increase stem length with no decrease in yield. Although yield per unit (tuber or transplant) was similar, high survivability of transplants resulted in more flowers per unit area and may be recommended in lieu of tubers. However, if disease and predators, possible reasons for poor emergence, are controlled, significant differences between planting materials would be unlikely.

\section{Centaurea}

Shade resulted in a linear reduction in flower yield, but stem length was shorter under full sun than in the shade (Table 1). The data suggest that high irradiance levels are particularly important for flowering but reduce stem length. The quadratic reduction in stem length due to shade suggests that no additional benefit in stem length occurs if shading is increased above $55 \%$. Although shading resulted in longer stems than ambient exposure, the reduction in yield indicates that shade is not necessary for commercial production of Centaurea americana 'Jolly Joker'.

\section{Echinops}

Shade affected all characteristics measured (Table 1). Yield was highest on plants grown under $55 \%$ shade, resulting in a quadratic response. A similar response to shade occurred with stem length. Plants grown under $55 \%$ and $67 \%$ shade had similar and longer flower stems than plants in full sun, resulting in a quadratic trend. The data suggest that yield and stem length of Echinops is reduced under full sun and growing them under 55\% shade may be effective in increasing yield and stem length. Use of $67 \%$ shade was of no additional benefit.

\section{Eryngium}

Shade resulted in a linear reduction of yield (Table 1). Although 55\% shade reduced yield by only two stems per plant compared to full sun plants, additional shade resulted in almost no flower stem formation. Flower stems were longest under $67 \%$ shade; however, so few flowers were produced that no economic gain due to longer stems would occur. Similar to Echinops, the response of stem length to shade was quadratic, indicating that $E r$ yngium planum should be grown in full sun. Since shading reduced yield and had little effect on stem length, shade is not recommended for flower production in Eryngium.

\section{Zantedeschia}

For all cultivars, yield was highest in ambient conditions and lowest in $67 \%$ shade (Table 2). Yield response to shade was quadratic for all but 'Black Magic', indicating that yield responded similarly to ambient illumination and $55 \%$ shade but that flower production was significantly reduced in $67 \%$ shade. Scape length increased as shading increased, regardless of cultivar (Table 2). Use of $67 \%$ shade resulted in longer scapes than $55 \%$ shade in 'Majestic Pink' and 'Black Magic' only, as shown by the linear trend (Table 2). The significant quadratic trend with 'Pink Perfection' and 'Pacific Pink' indicates that scapes were similarly long for $67 \%$ and $55 \%$ shade. Although all cultivars responded to shade, scape length of 'Majestic Pink' was $73 \%$ longer under $67 \%$ shade than under full sun, while scapes of 'Pacific Pink' were only $39 \%$ longer. 'Pink Perfection' and 'Black Magic' had $56 \%$ and $48 \%$ longer scapes, respectively, in $67 \%$ shade than in full sun. 
Spathe width was affected in all cultivars, except 'Majestic Pink', and other than for 'Black Magic', the response was quadratic, indicating no difference between the two shaded treatments (Table 2). Only with 'Black Magic' did spathe width continue to expand as density of shade increased. The data sug gest that, in the field, Zantedeschia should be provided with $\approx 55 \%$ shade to increase scape length and spathe width. Although the intensity of the response differed slightly with cultivar, trends were similar for all cultivars tested.

In summary, the addition of shade for fieldgrown cut-flower crops is species-dependent. Shade resulted in increases in stem length for all species; however, flower yield was reduced for Centaurea, Eryngium, and Zantedeschia; increased for Echinops, and was unaffected for Anemone as shade levels increased. Providing $55 \%$ shade may be a useful field treatment for
Echinops and Zantedeschia, but $67 \%$ shade could only be recommended for Anemone.

\section{Literature Cited}

Armitage, A.M. 1990. Specialty cut flowers. In: R.A. Larson (ed.). Introduction to floriculture. Academic, New York. /In press.)

Armitage, A.M., N.G. Seager, I.J: Warrington, and D.H. Greer. 1990. Response of Oxypetalum caeruleum to irradiance, temperature and photoperiod. J. Amer. Soc. Hort. Sci. 115:910914.

Armitage, A.M. and H.Y. Wetzstein. 1984. Influence of light intensity on flower initiation and differentiation in hybrid geranium. HortScience 19:114-116.

Bunt, A.C. 1973. Effect of season on the carnation (Dianthus caryophyllus) II. Flower production. J. Hort. Sci. 48:315-325.

Craig, R. and D.E. Walker. 1963. The flowering of Pelargonium hortorum Bailey seedlings as affected by cumulative solar energy. Proc. Amer. Soc. Hort. Sci. 83:772-776.
Halevy, A.H. 1984. Light and autonomous induction, p. 65-73. In: D. Vince-Prue, B. Thomas, and K.E. Cockshull (eds.). Light and the flowering process. Academic, New York.

Holley, W.D. 1959. Some major factors affecting quality and grade of carnations. Colo. Flower Growers Assn. Bul. 109:1-3.

Klusmeyer, J. and J.A. Martens. 1990. Diversified and specialized keys to cut flower success in Wisconsin. Grower Talks 53(11):22-24.

Post, K. and J.E. Howland. 1946. Influence of nitrate level and light intensity on the growth and production of greenhouse roses. Proc. Amer. Soc. Hort. Sci. 47:446-450.

U.S. Department of Agriculture. 1989. Floriculture crops, 1988 summary, $\mathrm{SpCr}$ 6-1 (89).

U.S. Department of Agriculture. 1990. USDA hardiness zone map. Misc. Publ. 1475.

U.S. Department of Agriculture. 1991. Floriculture crops, 1990 summary. SpCr 6-1 (91)

Zieslin, N. and A.H. Halevy. 1975. Flower bud atrophy in 'Baccara' roses. II. The effect of environmental factors. Scientia Hort. 3:383-391. 